\title{
Research on Diversified Evaluation Index System for Education Practice against Cloud Environment
}

\author{
Huang Lanying, Zhang pan, Tang zhiwen, Li zhimin
}

School of Computer and Information Science, Hubei Engineering University, Hubei, 432000, China

jkxhly@163.com

Keywords: cloud environment; diversified evaluation; educational practice; index system; questionnaires

\begin{abstract}
Cloud computing is extending its application to more and more fields, also including education field. The research focuses on the problem present in the education field, e.g. scattered education practice site, non-resident practice, simplex evaluation theme, etc. Under cloud environment, a method which combines qualitative research with quantitative research is introduced to try to establish a set of cloud environment-based education practice evaluation index system and has been used for material application. Such a formed diversified evaluation index system could effectively reflect the course of the education practice, make the evaluation about the student more objective, and effectively solve the problem about education practice evaluation for the purpose to provide theory support and reference for education practice evaluation.
\end{abstract}

\section{Introduction}

Education practice evaluation is an important link in the education practice course. New course reformation highlights comprehensive education practice evaluation which could not only help the student involved into practice find their weakness but also make the school able to has a detailed understanding about the practice situation of the student and accordingly launch necessary check and examination so that the student could effectively face the test from a quickly developed society[1,2]. The investigation proves that the prevailing education practice faces many problems: scattered practice site which makes the teacher difficult to perform theirs management and guidance; non-resident practice which makes the teacher who functions practice direction is impossible to track completely the practice course of each student, to master the practice situation of each student; the dogmatic learning evaluation makes the check and examination simplex, ignoring practice detail. The student and the entity where the student practices are unable to effectively participate in check, examination and evaluation [2,3]. The above problems make it difficult to fairly and objectively evaluate the current education practice. At the same time, the presence of cloud computing would impact greatly on the teaching. Mobile cloud computing is a booming computing model which displaces the data processing to Internet-based computer cluster from individual mobile phone, mobile learning tool, computer or server, which makes the student and teacher able to enjoy the services at any time and place, no geographical limitation, low cost, no demand for downloading, installation, maintenance and upgrade, etc. The arrival of the cloud computing era also promotes the development of the education practice platform. It means the education practice evaluation would face necessary innovation and exploration against new environment and philosophy[4,5,6]. In conclusion, how to launch a research on diversified evaluation about education practice against cloud computing is the topic of the paper.

The paper tries to elaborate how to utilize cloud computing platform to reform education practice evaluation in terms of process, method, subject, index and mode for the purpose to make the mode, subject, index, function and function of the evaluation diversified and developed a multidimensional student practice evaluation system which fits a scattered education practice situation and by which the student could make progress and improve themselves through practice. The paper hopes providing theoretical support and monitoring to student practice evaluation. 


\section{Research object and method}

\subsection{Research object}

Practice project of student from Hubei Engineering University 2014-2015.

\subsection{Research method}

The research mainly utilizes document literature, interview, questionnaire investigation and empirical research to investigate seventeen schools in Hubei Engineering University and exchanges with the practice support tutor by interview, phone and e-mail for their opinion and suggestion. In the questionnaire investigation, sixty questionnaires which aim at specialist were distributed with fifty-five recovered, one invalid, an recovery percent of $90 \%$. The questionnaire which aims at the student involved into practice covers 2000 person-time. A mobile cloud computing platform is structured to track the practice detail of each student in order to exercise and amend the structured diversified evaluation.

\section{Construction of education practice evaluation system based on cloud computing}

\subsection{Weight setup for diversified student practice evaluation index}

The index weight means a quantitative expression about relative significance of each index in the whole evaluation index system[7,8,9]. In general, in the hierarchical structure of the evaluation object system, each evaluation index at the bottom functions differently in the whole index system. When taking the information carried by each index into account, more information means greater weight and vice versa. When the index is considered which is used to evaluate the ability to distinguish the object, such an index with strong ability should receive high attention and carry high weight; on the other hand, such an index with weak ability should be beyond attention with low weight. The weight distribution in the paper uses analytical hierarchy process and expert consultation method (investigation \& statistical method). It is born on the base of the consultation to relevant practice teacher and expert, the problem about the evaluation of the education practice and the correction to the traditional evaluation index. It has been accepted by the lead and teacher involved into the education practice. The method to compute the total score for the practice: practice score $\times 80 \%+$ score for practice paper $\times 20 \%=$ total score (centesimal system). Where, practice score $=$ individual self-evaluation $* 15 \%+$ mutual evaluation among group members $* 20 \%+$ evaluation conclusion from teacher* $40 \%+$ practice school instructor evaluation $* 25 \% .\{0.15,0.2,0.25,0.4)$ is the weight set for practice score. Level distribution for practice project: $\mathrm{A}=$ =very satisfactory, $\mathrm{B}=$ Satisfactory, $\mathrm{C}=\mathrm{General}$, $\mathrm{D}=$ Not satisfactory=-Not satisfactory, score value respectively 1.0, 0.8, 0.7, 0.6, 0.5.

\subsection{Structure of education practice evaluation index system}

Fig. 1 showns the structure of the index evaluation system which is structured in cloud environment and aims at education practice. Where, the total practice score under diversified evaluation = practice score $\times 80 \%+$ practice paper score $\times 20 \%$. The diversified education evaluation against cloud environment is composed of practice evaluation and practice paper evaluation. Where, practice evaluation consists of individual self-evaluation, mutual evaluation among group members, teacher evaluation and evaluation from the tutor teacher from the school where the practice is implemented or the practice unit.

\subsection{Construction of content of education practice index}

The diversified evaluation system about education practice in Fig.1 consists of individual self-evaluation, mutual evaluation among group members, teacher evaluation , practice school instructor evaluation, and practice paper evaluation.

The grade- 2 index in the individual self-evaluation includes practice fruit, conclusion and introspection, coordination \& exchange, and process performance; the evaluation content includes practice fruit, works finished during practice, weekly practice report, practice report, practice news, practice exchange, practice briefing, practice attitude, and practice effect. Individual self-evaluation index design, as shown in Table 1. 


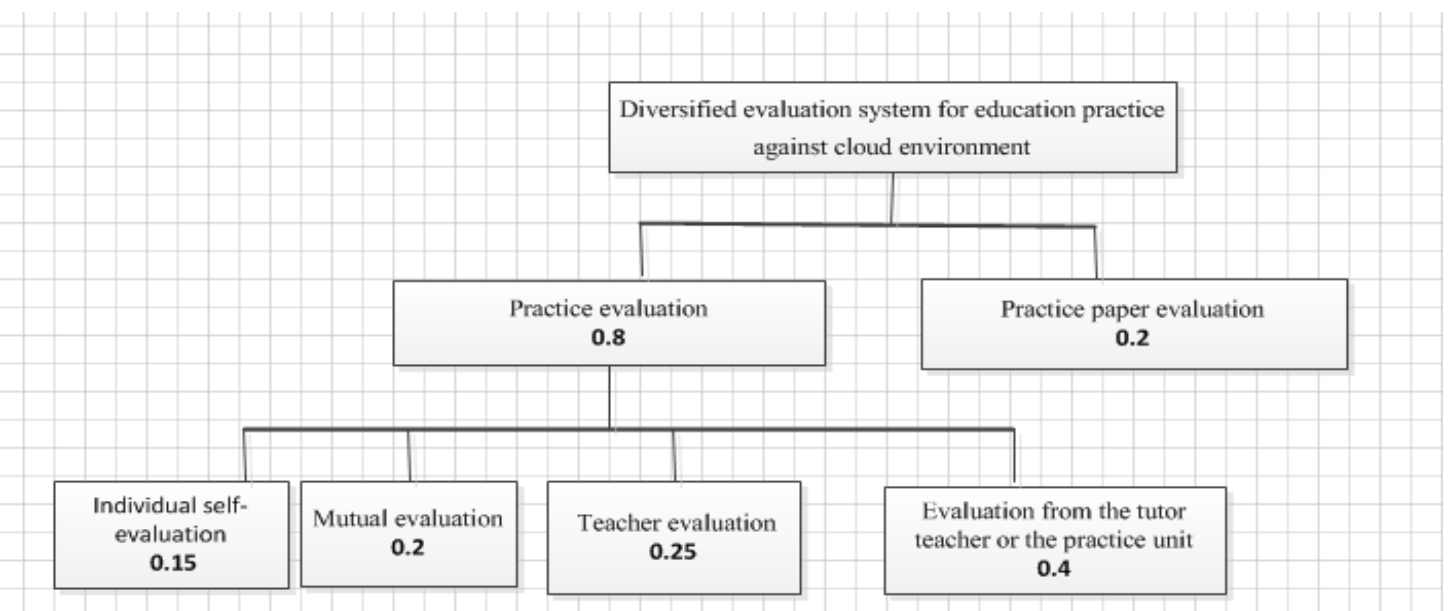

Fig.1 Structure of the index evaluation system

Table1 Individual self-evaluation index

\begin{tabular}{|c|c|c|c|c|c|c|c|c|c|c|}
\hline \multirow{2}{*}{$\begin{array}{l}\text { Level-1 } \\
\text { index }\end{array}$} & \multirow{2}{*}{\multicolumn{2}{|c|}{$\begin{array}{l}\text { Grade- } 2 \text { index and } \\
\text { evaluation content }\end{array}$}} & \multirow[t]{2}{*}{ Evaluation standard } & \multirow{2}{*}{$\begin{array}{c}\text { Rate } \\
\mathrm{d} \\
\text { score }\end{array}$} & \multicolumn{5}{|c|}{$\begin{array}{c}\text { Evaluation grade } \\
\text { and score }\end{array}$} & \multirow[t]{2}{*}{ Score } \\
\hline & & & & & A & B & C & $\mathrm{D}$ & $\mathrm{E}$ & \\
\hline \multirow{8}{*}{$\begin{array}{l}\text { Individual } \\
\text { self-evaluati } \\
\text { on } \\
0.12\end{array}$} & \multirow{2}{*}{$\begin{array}{l}\text { Practice } \\
\text { fruit or } \\
\text { works }\end{array}$} & $\begin{array}{c}\text { Practice } \\
\text { fruit }\end{array}$ & $\begin{array}{l}\text { Practice fruits shall be of certain professional level, finished and } \\
\text { submitted as schedule }\end{array}$ & 15 & & & & & & \\
\hline & & $\begin{array}{l}\text { Works } \\
\text { practice }\end{array}$ & Submit three or more practice works, with high quality & 15 & & & & & & \\
\hline & \multirow{2}{*}{$\begin{array}{l}\text { Conclusion } \\
\text { and } \\
\text { introspectio } \\
\mathrm{n}\end{array}$} & $\begin{array}{l}\text { Weekly } \\
\text { practice } \\
\text { report }\end{array}$ & $\begin{array}{l}\text { Complete weekly practice report as schedule and submit it in time. Its } \\
\text { content should be based on deep introspection with well organization. } \\
\text { The content should help greatly the self-growth of the student. }\end{array}$ & 10 & & & & & & \\
\hline & & $\begin{array}{c}\text { Practice } \\
\text { report }\end{array}$ & $\begin{array}{l}\text { Earnestly conclude and faithfully report the practice course and select } \\
\text { the meaningful experience and make deep conclusion; profoundly } \\
\text { introspect the harvest and shortcoming and further think deeply the } \\
\text { future learning and life. }\end{array}$ & 10 & & & & & & \\
\hline & \multirow[t]{2}{*}{$\begin{array}{l}\text { Coordinatio } \\
\mathrm{n} \text { and } \\
\text { exchange }\end{array}$} & $\begin{array}{c}\text { Practice } \\
\text { news }\end{array}$ & $\begin{array}{l}\text { Upload in first time practice news the number of which should be three } \\
\text { or more. The news should feature parallel image-text and be concise } \\
\text { and clear. }\end{array}$ & 15 & & & & & & \\
\hline & & $\begin{array}{l}\text { Practice } \\
\text { exchan } \\
\text { ge }\end{array}$ & $\begin{array}{l}\text { Positively launch or participate in group discussion; evaluate other's } \\
\text { fruit; the post published should be more than three, with reply for the } \\
\text { above post more than five. }\end{array}$ & 15 & & & & & & \\
\hline & \multirow[t]{2}{*}{$\begin{array}{l}\text { Practice } \\
\text { performance }\end{array}$} & $\begin{array}{l}\text { Practice } \\
\text { attitude }\end{array}$ & $\begin{array}{l}\text { Keep modest attitude; with earnest practice manner, high organization } \\
\text { sense of discipline; keep studious; consciously abide by rules and } \\
\text { regulations; no intentional absence or post absence during practice }\end{array}$ & 10 & & & & & & \\
\hline & & $\begin{array}{l}\text { Practice } \\
\text { effect }\end{array}$ & $\begin{array}{l}\text { Positively learn during practice; continual self-improvement, notable } \\
\text { progress present during practice with certain effect; recognized by lead } \\
\text { and colleague; able to follow practice outline to independently and } \\
\text { nicely complete various tasks }\end{array}$ & 10 & & & & & & \\
\hline
\end{tabular}

The grade- 2 index in the mutual evaluation among group members includes conclusion and introspection, coordination \& exchange and practice fruit; the evaluation content includes weekly practice report, practice report, practice exchange, practice briefing, works finished during practice; the mutual evaluation among group members is launched after practice completion and, the evaluation conclusion would be submitted online. The weekly practice report, practice report and works finished during practice mainly emphasize the works quality. The practice briefing mainly emphasizes whether the student involved into practice contribute the briefing completion earnestly and positively, and in a word, the evaluation focuses on the participation degree and attitude of the student. Mutual evaluation index design, as shown in Table 2. 
Table2 Mutual evaluation index

\begin{tabular}{|c|c|c|c|c|c|c|c|c|c|c|}
\hline \multirow{2}{*}{$\begin{array}{l}\text { Level-1 } \\
\text { index }\end{array}$} & \multirow{2}{*}{\multicolumn{2}{|c|}{$\begin{array}{l}\text { Grade- } 2 \text { index and } \\
\text { evaluation content }\end{array}$}} & \multirow{3}{*}{$\begin{array}{l}\text { Evaluation standard } \\
\text { Deliver three or more practice works during practice with high } \\
\text { quality }\end{array}$} & \multirow{3}{*}{$\begin{array}{c}\text { Rated } \\
\text { score }\end{array}$} & \multicolumn{5}{|c|}{$\begin{array}{l}\text { Evaluation grade } \\
\text { and score }\end{array}$} & \multirow[t]{2}{*}{ Score } \\
\hline & & & & & A & B & $\mathrm{C}$ & $\mathrm{D}$ & $\mathrm{E}$ & \\
\hline \multirow{5}{*}{$\begin{array}{c}\text { Mutual } \\
\text { evaluation } \\
0.16\end{array}$} & $\begin{array}{l}\text { Practice } \\
\text { fruit or } \\
\text { works }\end{array}$ & $\begin{array}{l}\text { Works } \\
\text { finished } \\
\text { during } \\
\text { practice }\end{array}$ & & & & & & & & \\
\hline & \multirow{2}{*}{$\begin{array}{l}\text { Conclusion } \\
\text { and } \\
\text { introspectio } \\
\mathrm{n}\end{array}$} & $\begin{array}{l}\text { Weekly } \\
\text { practice } \\
\text { report }\end{array}$ & $\begin{array}{l}\text { In time complete weekly practice report and submit as schedule. } \\
\text { The report should be based on serious introspection with great } \\
\text { help to self-growth }\end{array}$ & 10 & & & & & & \\
\hline & & $\begin{array}{l}\text { Practice } \\
\text { report }\end{array}$ & $\begin{array}{l}\text { Seriously conclude and faithfully report the two-month practice } \\
\text { course, and select the meaningful experience for deep conclusion } \\
\text { and profoundly introspect own harvest and shortcoming. Think } \\
\text { the future learning and life. }\end{array}$ & 10 & & & & & & \\
\hline & \multirow[t]{2}{*}{$\begin{array}{l}\text { Coordinatio } \\
\mathrm{n} \text { and } \\
\text { exchange }\end{array}$} & $\begin{array}{l}\text { Practice } \\
\text { exchange }\end{array}$ & $\begin{array}{l}\text { Positively launch and participate in group discussion; in time } \\
\text { give feedback and review to other's article; positively put forward } \\
\text { the problem encountered during practice and discuss with other; } \\
\text { keep active in the forum }\end{array}$ & 20 & & & & & & \\
\hline & & $\begin{array}{l}\text { Practice } \\
\text { briefing }\end{array}$ & $\begin{array}{l}\text { Positively and seriously conceive and edit the practice briefing; } \\
\text { actively assist other to try to edit a characteristic group briefing. } \\
\text { The evaluation should emphasize on whether the student } \\
\text { contributes the publication of the practice briefing not on the } \\
\text { quality of the briefing itself. }\end{array}$ & 10 & & & & & & \\
\hline
\end{tabular}

The grade-2 index in the teacher evaluation includes conclusion and introspection, practice fruit and coordination \& exchange; the evaluation content includes weekly practice report, practice report, practice fruit, practice exchange and practice briefing. The score of the practice briefing is group-based. The score is same for each member of the group.

The grade- 2 index in the practice school instructor evaluation includes practice attitude, practice performance and report; the evaluation content includes interpersonal skills, practice performance and practice progress. The standard for the evaluation from the tutor teacher from the school where the practice is implemented based on the practice unit evaluation form formulated by the practice school.

The grade- 2 index in the practice paper evaluation includes paper title selection, paper content, and paper analysis and paper structure. The evaluation standard is formed based on the standard for excellent paper for the graduate. Evaluation on practice paper index design, as shown in Table3.

Table 3 Evaluation On practice paper index

\begin{tabular}{|c|c|c|c|c|c|c|c|c|c|}
\hline \multirow{2}{*}{$\begin{array}{c}\text { Level-1 } \\
\text { index }\end{array}$} & \multirow{2}{*}{$\begin{array}{l}\text { Grade-2 index } \\
\text { and } \\
\text { evaluation } \\
\text { content }\end{array}$} & \multirow{2}{*}{ Evaluation standard } & \multirow{2}{*}{$\begin{array}{l}\text { Rate } \\
\text { d } \\
\text { scor } \\
\text { e }\end{array}$} & \multicolumn{5}{|c|}{$\begin{array}{l}\text { Evaluation grade } \\
\text { and score }\end{array}$} & \multirow{2}{*}{ Score } \\
\hline & & & & A & B & $\mathrm{C}$ & $\mathrm{D}$ & $\mathrm{E}$ & \\
\hline \multirow{4}{*}{$\begin{array}{c}\text { Evaluatio } \\
\mathrm{n} \\
\text { On } \\
\text { practice } \\
\text { paper } \\
0.2\end{array}$} & $\begin{array}{c}\text { Paper title } \\
\text { selection }\end{array}$ & $\begin{array}{l}\text { Relatively good paper title selection, able to apply the professional knowledge } \\
\text { learned to the practice effectively; able to raise the problem and analyze the } \\
\text { problem }\end{array}$ & 25 & & & & & & \\
\hline & Paper content & $\begin{array}{l}\text { Paper should show certain individual review and practicability, with certain } \\
\text { theoretical depth. }\end{array}$ & 25 & & & & & & \\
\hline & Paper analysis & $\begin{array}{l}\text { The material should be representative and real, with both quantitative analysis } \\
\text { and qualitative analysis. The paper should present sufficient persuasion. }\end{array}$ & 25 & & & & & & \\
\hline & Paper structure & $\begin{array}{l}\text { The paper should keep strict structure, high logicality, clear hierarchy, refined } \\
\text { language, tidy writing and right \& regular chart. }\end{array}$ & 25 & & & & & & \\
\hline
\end{tabular}

\section{4. $\quad$ Practice effect}

In order to demonstrate the effectiveness of the diversified evaluation for the education practice against cloud platform environment[10], the education practice of the 2014 graduate from Hubei Engineering University is sampled. The education practice covers seventeen schools where 2000 
person-time are sampled. The designed index system is placed in the education practice platform against cloud computing environment for empirical study. In order to assure fluent practice, a diversified evaluation index system is designed which consists of individual self-evaluation, mutual evaluation among group members, teacher evaluation and conclusive evaluation that would be launched after the completion of the education practice by online operation. The student and teacher could make self-evaluation and mutual evaluation at any time and any site. After the completion of the education practice, questionnaire survey is launched with 2000 questionnaires issued in which 1800 questionnaires are effectively recovered. In the 1800 effective questionnaires, 71\% expresses very satisfactory or basically satisfactory for the diversity of the evaluation content (include practice fruit, weekly practice report, practice paper, practice report, etc.), only 3\% expressing unsatisfactory. 83\% expresses satisfactory for the diversity of the evaluation form (in terms of filling satisfaction degree, writing self-evaluation report, voting and rating), with only $8 \%$ expressing unsatisfactory. $71 \%$ expresses very satisfactory for the diversity of the evaluation topic (teacher, student, practice unit), with residual 29\% expressing basically satisfactory; in general, the student shows satisfactory to the diversified evaluation used by the education practice project.

\section{Conclusion}

The index dimension designed by the study includes the individual self-evaluation, the mutual evaluation among group members, teacher evaluation, practice school instructor evaluation and the practice paper evaluation. The evaluation made by the teacher and student in the study is implemented online. The material used for evaluation is all present in the cloud computing environment for education practice. Such an open environment could eliminate possible mutual plagiarization and promote the mutual learning. The online evaluation against cloud computing environment would greatly ease the work load of the teacher who just needs checking the relevant option and make relevant supplement to complete his (her) evaluation. Such would greatly improve the work efficiency of the teacher.

\section{Acknowledgment}

This work is partly supported by Hubei Provincial Department of Education Humanities and Social Sciences Project (No.15Y141), Hubei University of Engineering of Education research project(No.2014B10), Hubei College Students Innovation and Entrepreneurship Training Program (NO.201510528026).

\section{References}

[1]. Zhu Min, Influence of “Cloud computing” on education, Education Forum Journal, 2010, (21): 66-67.

[2]. Wang Kai, “Development of school-based student assessment study”, Shanghai: East China Normal University Press, 2009. (In Chinese)

[3]. Huo li-Rong, Yu Miao, Gao Yi-dong., “Cloud computing support groups Collaborative Learning Environment”, Chinese information technology education, 2010, (05): 77-79. (In Chinese)

[4]. Huang Zu-Miao, “Cloud computing applications evaluated in Junior IT Education”, Education Forum Journa, 2015 (8): 231-232. (In Chinese)

[5]. Xiong Guomin, "Situation Normal College Students Practice and Teaching Ability Investigation”, Guizhou Educational Institute, 2009, 25 (8). (In Chinese)

[6]. Yun Li, "Current clinical evaluation of Normal University Education Problems and Countermeasures”, Inner Mongolia Normal University: Science Education, 2012, (3): 41-43. (In Chinese) 
[7]. Wang Pengfei, "Multidimensional Assessment System of Higher Vocational Students Practical Ability cloud computing environment”, Vocational Education Research, 2012, (9): 149-150. (In Chinese)

[8]. Xie Limin, Chu Huiling, "Multiple evaluation system to develop evaluation criteria Thoughts", Global Education, 2009, 02: 22. (In Chinese)

[9]. Hu Liping, "Evaluation of the diverse student under Moodle Environment - Shanghai World Foreign Language Middle School junior class, for example inquiry”, Shanghai: Shanghai Normal University, 2008, 4:1-2.

[10].Wang Yajun, “Cloud-based Personalized Learning Space”, Information Technologies in Education, 2013, (11): 41-42.(In Chinese) 